\title{
Information Systems Supporting Product Exports of the Agricultural Sector of the Economy
}

\author{
O.V. Mamai ${ }^{1, *}, M . V$. Kitaeva $^{2}$ and B. Molloy ${ }^{3}$ \\ "Corresponding author: ovm1977@yandex.ru \\ ${ }^{1}$ Samara State Agricultural Academy, Samara, Russia \\ ${ }^{2}$ Samara State University of Economics, Samara, Russia \\ ${ }^{3}$ University College Cork, Cork City, Ireland
}

\begin{abstract}
Export is one of the difficult foreign economic problems of Russia. It has always been and remains a key issue of national development, and it is also an important source of currency for meeting the priority needs of the national economy. The state of export largely determines the process of Russia's integration into the world economy. The purpose of the study is to analyze information systems for supporting exports in the Russian Federation, as the main information component when making export decisions. The study considers the existing information systems for supporting exports in the Russian Federation, and for evaluating export support systems for the agricultural sector of the economy. The methodological basis of the study was dialectic principles, methods of system analysis of economic phenomena: analysis and synthesis, the method of scientific abstraction, the method of expert evaluation, etc. The study outlines the main trends in the improvement of information systems for supporting exports in the Russian Federation.
\end{abstract}

Keywords: agricultural sector, export, information support, information system.

\section{Introduction}

Russian legislation has more than 3,000 regulations directly or indirectly reflecting issues that concern export. However, only a few regulations consider the concept of export. The main one is the Federal Law dated December 8, 2003 No. 164-FL (as amended on July 28, 2012) “On the Basics of State Regulation of Foreign Trade Activity” [1]. In accordance with it, export of goods is export of goods from the Russian Federation without an obligation to re-import. The fact of export is recorded at the time when the goods cross the customs border of the Russian Federation, the services and rights to the results of intellectual activity are provided. Export of goods also includes separate commercial operations without exporting goods abroad from the customs territory of the Russian Federation, in particular when a foreign person buys goods from a Russian person and transfers it to another Russian person for processing and subsequent exporting of processed goods abroad.

\section{Problem Statement}

Export is one of the difficult foreign economic problems of Russia. It has always been and remains a key issue of national development, and it is also an important source of currency for meeting the priority needs of the national economy. The state of export largely determines the process of Russia's integration into the world economy [2]. New trends in the global economy and the international division of labor, the increased competition in foreign markets, the exhaustion of extensive factors in the development of Russian export and the need for technological modernization of its export potential require scientific analysis. The current scientific research in addressing Russian export issues is imposed by the needs of economic theory and practice in identifying and describing new trends and patterns of this complex process. In addition, scientific research is caused by the need to protect foreign economic interests and ensure the economic security of Russia.

\section{Research Questions}

Business management requires informed decisions based on a comprehensive study of the state of markets, conditions and costs of delivering goods to them, conditions and costs of exporting goods from the country and assessing risks. The exporter has to interact with companies engaged in marketing research, carriers, customs representatives, patent attorneys, banks and various authorities both in the territory of the Russian Federation and abroad. All this necessitates the development of the effective information and consultation system for supporting exports of Russian products in general, and the agricultural sector in particular, and for carrying out a rational assessment of regional information potential [3]. 


\section{Purpose of the Study}

The purpose of the study is to analyze information systems for supporting exports in the Russian Federation, as the main information component when making export decisions. The study considers the existing information systems for supporting exports in the Russian Federation, and for evaluating export support systems for the agricultural sector of the economy.

\section{Research Methods}

The methodological basis of the study was dialectic principles, methods of system analysis of economic phenomena: analysis and synthesis, the method of scientific abstraction, the method of expert evaluation, etc. The study is based on data from the Ministry of Economic Development of the Russian Federation and the Ministry of Agriculture of the Russian Federation.

\section{Findings}

According to the data of the Russian Export Center JSC, taking into account the preliminary data of the Federal Customs Service of the Russian Federation, Russia's exports in January-August 2018 [4] amounted to 286 billion dollars (hereinafter - US dollars). Compared with January-August 2017, it grew by 62.9 billion dollars or $28.2 \%$.

The main contribution to the increase in exports was made by fuel, which accounted for $74 \%$ of the total increase. In addition, metal products provided $12 \%$ of the gain; as for other groups the contribution of food and agricultural raw materials was the most significant $(6 \%)$.

The positive dynamics of exports to the same period of the previous year was recorded for the 22nd month in a row. The growth was achieved in many types of products, primarily due to the increase in world prices, and the expansion of physical volumes of supplies played a secondary role.

Fuel is the basis of Russian exports, as noted above. Its deliveries in January-August 2018 amounted to $\$ 184.3$ billion, or $64.4 \%$ of the total.

Other important product groups are:

- Metal products - 29.97 billion dollars, 10.5\%;

- Chemical products - 17.4 billion dollars, $6.1 \%$;

- Engineering products - 17.3 billion dollars, $6 \%$;

- Food and agricultural raw materials - 15.1 billion dollars, $5.3 \%$.

The value of other groups is small, for example, textiles, clothing, shoes -0.8 billion dollars, $0.3 \%$.

Thus, with a general increase in exports by $28 \%$, the highest growth rates were shown by fuel $(+34 \%)$, metal products $(+33 \%)$ and food and agricultural raw materials $(+30 \%)$.

Analysis of monthly monitoring of exports of the agricultural sector is given in Table 1.

Table 1.The volume of exports of the agricultural sector of the Russian Federation (data for October 2018)

\begin{tabular}{|l|c|c|c|c|}
\hline Products & $\begin{array}{c}\text { Weight, } \\
\text { thousand } \\
\text { tons }\end{array}$ & $\begin{array}{c}\text { Dynamics to the } \\
\text { level of the } \\
\text { previous year, \% }\end{array}$ & $\begin{array}{c}\text { Cost, million } \\
\text { dollars }\end{array}$ & $\begin{array}{c}\text { Dynamics to the } \\
\text { level of the } \\
\text { previous year, \% }\end{array}$ \\
\hline Grain & 44948 & 40,66 & 8419 & 51,50 \\
\hline Fish & 758 & 27,32 & 2424 & 31,24 \\
\hline Sugar & 308 & $-16,43$ & 143 & $-25,79$ \\
\hline Milk & 52 & $-21,25$ & 51 & $-22,93$ \\
\hline Meat & 219 & 14,84 & 268 & 5,90 \\
\hline
\end{tabular}

Source: compiled by: O.V. Mamai [5]

According to Table 1, grain (the increase of 40.66\%), fish (the increase of $27.32 \%$ ) and meat (the increase of $14.84 \%$ ) make the main increase in exports of products of the agricultural sector of the economy. The remaining product groups do not currently provide a steady increase in exports [6]. However, the presented data indicate that at present a modern and effective system for supporting exports of the agricultural sector of the economy is being formed in the Russian Federation [7, 8].

The study shows [9] that during the implementation of the export project at all its stages, managers and employees of the organization planning and carrying out export activities have to search and analyze a large amount of information. Business management requires informed decisions based on a comprehensive study of the state of markets, conditions and costs of delivering goods to them, conditions and costs of exporting goods from the country and assessing risks. The exporter has to interact with companies engaged in marketing research, carriers, customs representatives, patent attorneys, banks and various authorities both in the territory of the Russian Federation and 
abroad. All this necessitates the development of the effective information and consultation system for supporting exports of Russian products in general, and the agricultural sector in particular.

The most developed and effective information resource for supporting exports is currently the information retrieval system "Single Portal of Foreign Economic Information" developed by the Ministry of Economic Development of the Russian Federation. Its main goal is to develop and improve the foreign economic activity of the Russian Federation. The content of the system is produced by structural units of the Ministry and trade missions of the Russian Federation in foreign countries. In addition, information for the content is provided by administrations of the subjects of the Russian Federation, business and industry unions and associations, as well as directly by Russian participants in foreign economic activity. The Department for Development and Regulation of Foreign Economic Activity of the Ministry of Economic Development of Russia provides the functioning of the information resource. The main tasks of the system are information and consulting support for Russian and foreign participants in foreign economic activity, as well as support for the promotion of Russian goods and services to foreign markets.

The Single Portal of Foreign Economic Information provides various services for exporters. So, the section "Help the exporter" contains the following subsections:

- Public services in the field of foreign economic activity, provided in electronic form, contain a list of public services that the exporter can receive in remote access for legitimate export activities;

- Intergovernmental commissions - commissions on trade and economic cooperation with foreign countries (IGC), committees and working groups working within the framework of IGC, whose activities are aimed at developing a bilateral cooperation between the Russian Federation and foreign countries, which are an effective tool for solving problems of mutual interest. Due to IGC, the investment and interregional cooperation is being developed, transport problems are being solved, relations between customs services are being strengthened, and the interaction in the field of innovations is reaching a new level;

- Trade restrictions - a review of existing restrictions on the access of Russian goods to foreign markets;

- Market protection tools - a description of special protective measures in connection with the increased import to the customs territory of the state, anti-dumping measures in connection with the dumping import to the customs territory of the state, reimbursement measures in connection with subsidized import to the customs territory of the state, as well as mechanisms for their application;

- Financial support for exports - a review of state guarantees, concessional lending to foreign buyers, financing of export operations by Vnesheconombank, insurance of export credits and investments, financing of export operations by ZAO Roseximbank, reimbursement for a part of costs of transporting agricultural and food products;

- Non-financial export support - a description of trade and political measures aimed at expanding access of Russian export to foreign markets and elimination of non-financial trade barriers,

- Export support in the subjects of the Russian Federation - an overview of the features of export activities for the selected regions of Russia;

- Electronic trading platforms - this section is intended to inform Russian exporters to increase the use of electronic channels for the promotion and sale of Russian goods;

- Foreign resources for tenders - a list of foreign resources for tenders, indicating the country and language of the resource;

- Search for partners and markets - the ability to search for markets for companies, tenders, commercial inquiries, exhibitions and fairs, statistics, monitoring. Users are given the opportunity to search for regulatory documents, market conditions, as well as trade missions and non-profit organizations supporting Russian companies abroad. The search can be carried out by the country of export, and by the name of the product.

Thus, the users of the Single Portal of Foreign Economic Information can get a variety of information necessary for effective exports.

A similar information system for exporters of products of the agricultural sector can be found on the website of the Ministry of Agriculture of the Russian Federation.

This section is called "Support for export of agricultural products" and contains the following subsections:

- A working group on exports of agricultural products - contains materials of meetings of the interdepartmental working group, as well as regulatory documents to support exports of agricultural products;

- Analytical support - information about the complex of measures for specialized support of Russian agricultural producers - exporters of agricultural products by industries and country areas, as well as information and analytical support of the Ministry of Agriculture of Russia on exports of agricultural products (under development);

- Access to foreign markets - an overview of the conditions for access of countries (administrative, technical, veterinary and phyto-sanitary) to foreign markets (under development);

- Logistics - information on subsidies to Russian organizations for reimbursement of a part of costs of transporting agricultural and food products by land, including rail, aimed at supporting exports of agricultural and food products;

- Marketing support - information on reimbursement of a part of costs of exporting companies to finance a part of costs associated with the promotion of high-tech, innovative and other products and services to foreign markets through participation in international congress and exhibition events and specialized business missions. Financing a part of costs in order to implement measures aimed at promoting the products of the agro-industrial complex to foreign markets, with the exception of exhibition and fair activities, as well as characterizing work to create a positive image of Russian agricultural products in the minds of the target audience and in importing countries; 
- Educational programs - educational materials for export-oriented enterprises, which are aimed at helping entrepreneurs start export activities in accordance with the requirements of Russian and foreign legislation in the current economic conditions;

- Support for small and medium-sized businesses - information on the cooperative movement, opportunities for obtaining loans, etc.

In general, the information resource of the Ministry of Agriculture of the Russian Federation for exporters of products of the agricultural sector of the economy makes a favorable impression. However, the study has showed that most of the subsections are under development or they are not filled with relevant information. Therefore, it is necessary to solve this problem in the near future.

\section{Conclusion}

Thus, the results of the study are the following:

1) Recently, there has been an increase in exports, especially in products of the agricultural sector of the economy;

2) It is necessary to have relevant information about the situation in sales markets for effective export activities;

3) The issue of informing exporters in the Russian Federation is solved using the resources of the Single Portal of Foreign Economic Information.

4) The information system of the Ministry of Agriculture of the Russian Federation has been created for exporters of products of the agricultural sector of the economy, which is currently at the stage of filling information.

5) It should be remembered that these information resources will be actively used by exporters only if they contain relevant information in sufficient quantity for making export decisions.

Consequently, the existing information systems for supporting exports can help get information about the foreign market, contacts of potential suppliers and buyers, carriers, calculation of the cost of delivery of goods, etc. However, they have to be filled with information, relevant and known to potential and actual exporters.

\section{References}

1. Federal'nyj zakon "Ob osnovakh gosudarstvennogo regulirovaniya vneshnetorgovoj deyateljnosti" ot 08.12 .2003 No. 164-FZ. Retrieved from: http://www.consultant.ru/cons/cgi/online.cgi?req=doc\&base=LAW \&n=312194\&fld=134\&dst=1000000001,0\&rnd= 0.95937116505181\#020795980394250546. Accessed: 28.07.2018 (2003). [in Rus.].

2. A.V. Petrikov, The development of exports of products of the Russian agriculture: problems and solutions. Nikon Readings, VIAPI, 22, 3-4 (2017).

3. S.I. Ashmarina, G.R. Khasaev, V.V. Mantulenko, S.V. Kasarin, E.M. Dorozhkin, Methodical bases for the regional information potential estimation. International Journal of Environmental and Science Education, 11(15), 7715-7725 (2016).

4. Analytical reference. Overview of the agricultural market conjuncture 2018. Moscow: Center for Analytics (2018).

5. Analytical reference. The development of total and non-oil exports of Russia in January-August 2018. Moscow: JSC "Russian Export Center" (2018).

6. A.A. Lichman, Dynamics of agricultural exports in Russia in 1992-2015 in the WTO and FAO databases. Nikon Readings, VIAPI, 22, 24-27 (2017).

7. Y.A. Voiteshonok, System of state support of export to the Russian Federation: A condition and development prospects. Moscow: All-Russian Academy of Foreign Trade (2012).

8. A.A. Zharinov, Improving the system of state support of exports in the Russian Federation. Moscow: All-Russian Academy of Foreign Trade (2010).

9. O. Mamai, I. Mamai, Optimization of the management mechanism for the innovative development of the region's agricultural sector. In F.M. Antanas Maziliauskas (Ed.), Proceedings of the $8^{\text {th }}$ international scientific conference Rural Development 2017: Bio-economy Challenges, 1167-1173, Aleksandras Stulginskis University (Lithuania) (2017). 